\title{
ANALYSIS OF EXPERIENTIAL MARKETING EFFECT ON TOURIST SATISFACTION LEVELS AT THE TOURIST RESTAURANT IN BELITUNG DISTRICT
}

\author{
Pelliyezer Karo-Karo \\ Politeknik Pariwisata Palembang \\ pelliyezer@poltekpar-palembang.ac.id
}

Received: January 22, 2020/Reviewed: May 7, 2020/ Published : May 25, 2020

\begin{abstract}
This study is to determine the effect of experiential marketing on the level of tourist satisfaction in tourist restaurants in Belitung Regency. Experiential marketing that was studied included the variables of sense, feel, think, act and relate. Data collection techniques used were interviews, questionnaires, and observations. The data analysis model used is multiple linear regression analysis with hypothesis testing carried out simultaneously and partially. Research on 115 samples shows that independent variables consisting of sense, feel, think, act and relate simultaneously have a very strong influence on the dependent variable tourist satisfaction level. While partially, the study produced that there are three variables namely feel, act and relate which have a significant influence on the level of tourist satisfaction, where the feel variable is the most dominant.
\end{abstract}

Keywords: experiential marketing, sense, feel, think, act, relate, tourist restaurant, tourist satisfaction

*correspondence author, email: pelliyezer@poltekpar-palembang.ac.id

Naskah diterima: 22 Januari 2020/ Naskah ditelaah : 7 Mei 2020/

Naskah dipublikasi : 25 Mei 2020

\section{ANALISIS PENGARUH EXPERIENTIAL MARKETING TERHADAP TINGKAT KEPUASAN WISATAWAN PADA RUMAH MAKAN WISATA DI KABUPATEN BELITUNG}

\begin{abstract}
ABSTRAK
Penelitian ini untuk mengetahui pengaruh experiential marketing terhadap tingkat kepuasan wisatawan pada rumah makan wisata di Kabupaten Belitung. Experiential marketing yang diteliti mencakup variabel sense, feel, think, act dan relate. Teknik pengumpulan data yang digunakan adalah wawancara, kuesioner, dan observasi. Model analisis data yang digunakan adalah analisis regresi linier berganda dengan pengujian hipotesis dilakukan secara simultan dan parsial.
\end{abstract}


Penelitian terhadap 115 sampel menunjukkan hasil bahwa variabel bebas yang terdiri dari sense, feel, think, act dan relate secara simultan memiliki pengaruh yang sangat kuat terhadap variabel terikat tingkat kepuasan wisatawan. Sedangkan secara parsial, penelitian menghasilkan bahwa terdapat tiga variabel yaitu feel, act dan relate yang memiliki pengaruh signifikan terhadap tingkat kepuasan wisatawan, dimana variabel feel merupakan paling dominan.

Kata kunci: experiential marketing, sense, feel, think, act, relate, rumah makan wisata, kepuasan wisatawan

\section{PENDAHULUAN}

Sektor pariwisata diproyeksikan sebagai penghasil devisa terbesar Indonesia di tahun 2019, terlihat dari pencapaian devisa sektor pariwisata pada 2018 mencapai 19,3 miliar dollar AS atau melampaui target 17 miliar dollar AS, sedangkan target tahun 2019, devisa pariwisata akan menyumbang 20 miliar dollar AS. Pariwisata Indonesia merupakan salah satu industri pariwisata dengan pertumbuhan paling cepat di dunia. Travel and Tourism Competitiveness Index (TTCI) oleh World Economic Forum (WEF) menunjukkan pertumbuhan positif daya saing industri pariwisata Indonesia di dunia, peringkat 70 pada tahun 2015 dan terus meningkat hingga mencapai peringkat 40 di tahun 2019, sedangkan secara regional, pariwisata Indonesia berada di peringkat 4 di Asia Tenggara. Hal ini menunjukkan pertumbuhan pesat industri pariwisata Indonesia, yang harus terus dibenahi dalam berbagai faktor pendukung sektor pariwisata sehingga pada masanya akan mampu meraih TTCI dengan peringkat 30 dunia.

Pemerintah Indoenesia memiliki peranan penting dalam menggali potensi dan membuat kebijakan terhadap pengembangan kepariwisataan, sehingga masyarakat lokal tergugah kesadarannya untuk menggali potensi dan bergerak membangun desa maupun kota masing-masing. Salah satu strategi yang tumbuh subur dan menjadi stakeholder yaitu strategi pengembangan desa wisata melalui pemberdayaan masyarakat.

Salah satu model pembangunan kepariwisataan di Indonesia melalui pengembangan desa wisata berbasis pendampingan perguruan tinggi. Politeknik Pariwisata Palembang dibawah naungan Kementerian Pariwisata dan Ekonomi Kreatif, memiliki wilayah kerja hingga Provinsi Bangka Belitung. Kabupaten Belitung merupakan bagian dari Kepulauan Bangka Belitung, yang terbagi menjadi lima kecamatan dengan Tanjungpandan merupakan ibukota kabupaten. Lokus penelitian juga diperkuat dengan dasar Peraturan Pemerintah Republik Indonesia No. 6 Tahun 2016 tentang Kawasan Ekonomi Khusus Tanjung Kelayang. 


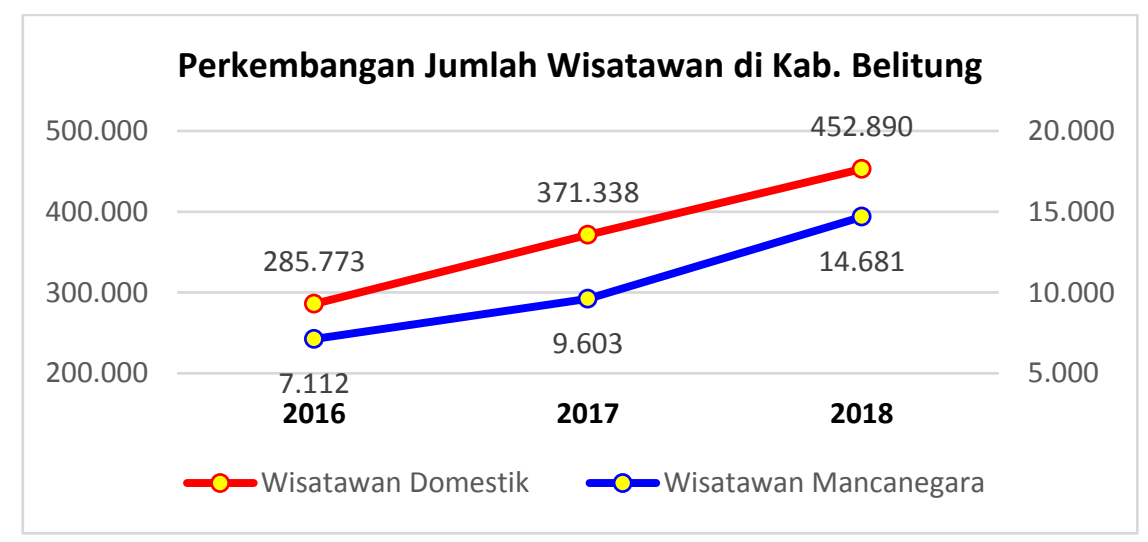

Gambar 1. Grafik Perkembangan Jumlah Wisatawan di Kabupaten Belitung Sumber: BPS Kabupaten Belitung, diolah

Publikasi Badan Pusat Statistik (BPS) Kabupaten Belitung menunjukkan jumlah wisatawan berkunjung ke Kabupaten Belitung terus bertambah setiap tahunnya. Peningkatan jumlah wisatawan domestik sebesar $23,04 \%$ terjadi pada tahun 2017 dari tahun sebelumnya, begitu juga di tahun 2018 peningkatan tercatat sebesar $18 \%$ dari tahun sebelumnya. Sejalan dengan hal tersebut, jumlah wisatawan mancanegara juga meningkat sebesar 26.94\% di tahun 2017 dan $34,59 \%$ di tahun 2018 dari tahun sebelumnya, dimana rata-rata komposisi wisatawan mancanegara sebesar 2,77\% selama 3 tahun terakhir.

Fakta positif tersebut menjadi salah satu dasar bagi Politeknik Pariwisata Palembang untuk mengimplementasikan tugasnya yang tertuang dalam Tri Dharma Perguruan Tinggi dalam kaitannya pada sektor pariwisata melalui pembinaan desa wisata. Desa yang dipilih bernama Desa Terong. Desa wisata Terong adalah sebuah desa berlokasi di Kecamatan Sijuk, letaknya sangat strategis di jalur pelintasan pesisir pantai utara Pulau Belitung dan jalur lintasan pariwisata menuju destinasi wisata Tanjung Pandan, Tanjung Kelayang dan Tanjung Tinggi.

Pengembangan desa wisata dapat dilakukan melalui pemberdayaan masyarakat, dengan membantu masyarakat desa wisata dalam membangun dan mengelola usaha akomodasi dan makan minum. Dalam hal ini makan minum yang dimaksud menitikberatkan pada usaha rumah makan. Namun dalam membuka usaha dalam bidang makan minum diperlukan standar dan pengetahuan dalam mengelola produk maupun layanan yang akan disuguhkan kepada konsumen yaitu wisatawan. Oleh karena itu penting sekali bagi pelaku usaha, khususnya penyedia jasa makanan dan minuman untuk menjaga kualitas pelayanan agar para wisatawan merasa puas. 


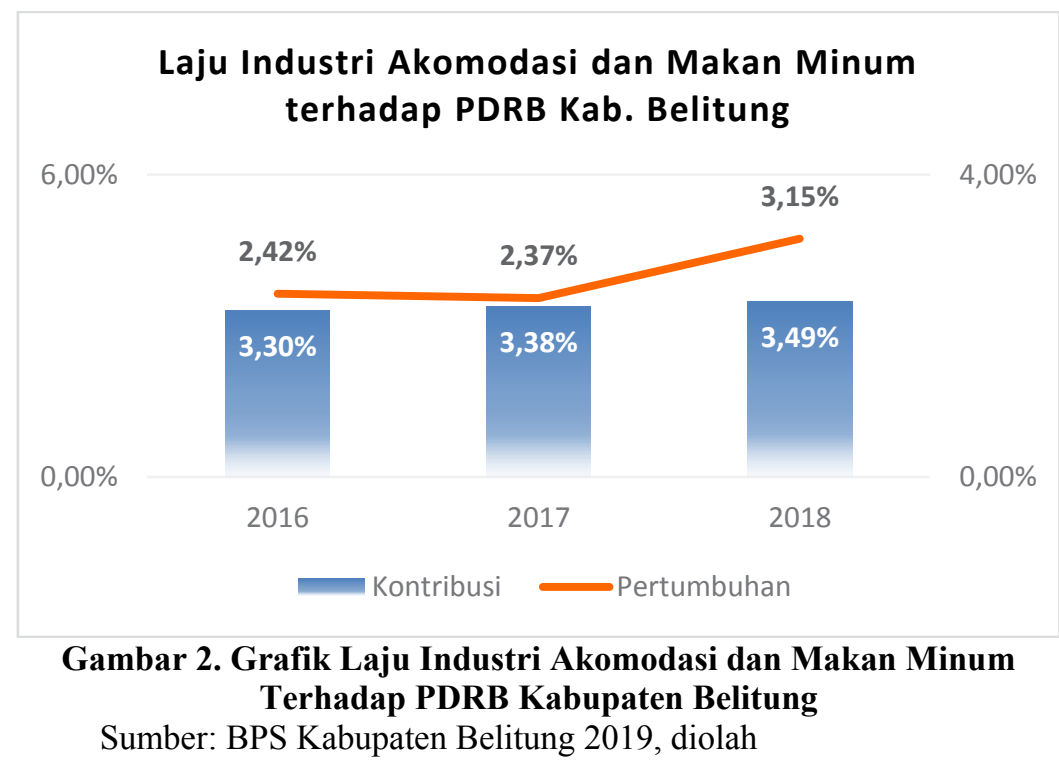

Berdasarkan lapangan usahanya, sektor pariwasata di Kabupaten Belitung terwakilkan oleh industri akomodasi dan makan minum dengan porsi kontribusi di tahun 2018 hanya sebesar 3.49\% terhadap Produk Domestik Regional Bruto (PDRB) di tingkat kabupaten. BPS Kabupaten Belitung mencatat, laju pertumbuhannya setiap tahun tidak signifikan dengan rata-rata pertumbuhan di tiga terakhir hanya tercapai di angka 2,65\%. Hal ini mengindikasikan bahwa sektor pariwisata belum memiliki value added dan berdampak besar bagi perekonomian masyarakat di Kabupaten Belitung secara umum dan Desa Terong secara khusus. Berangkat dari paparan data tersebut, dilakukan penelitian yang berkaitan dengan industri jasa makanan dan minuman di Kabupaten Belitung secara umum dan Desa Terong secara khusus yang akan mampu memberikan dampak perekonomian bagi masyarakat sekitar.

Bagi konsumen (wisatawan), pengalaman yang diberikan oleh perusahaan (rumah makan wisata) merupakan langkah awal untuk menilai bagaimana perusahaan tersebut dapat memberikan kepuasan sesuai dengan ekspektasi yang diinginkan oleh konsumen. Secara umum, kepuasan pelanggan ditentukan oleh terpenuhi tidaknya harapan pelanggan. Definisi umum tersebut mengacu pada paradigma expectancy-disconfirmation. Berdasarkan paradigma ini, pelanggan membentuk harapan, harapan ini akan menjadi standar untuk menilai kinerja aktual suatu produk atau jasa. Jika apa yang diharapkan pelanggan terpenuhi, maka akan terjadi confirmation. Dengan kata lain, pelanggan puas. Sebaliknya, jika apa yang diharapkan pelanggan tidak terpenuhi, maka akan terjadi disconfirmation.

Dalam mempertahankan dan meningkatkan kepuasan konsumen, dalam hal ini adalah wisatawan, industri harus memperhatikan hal-hal yang dapat mempengaruhi minat beli konsumen seperti harga, produk, lokasi, pelayanan, informasi, dan konsep pemasaran, dimana hal sama juga dilakukan pada sektor pariwisata. Kepuasan kosumen dapat diteliti melalui penerapan konsep experiential marketing yang dilakukan, dengan mengidentifikasi 5 determinan pengalaman pelanggan yaitu sense (panca indera), feel (perasaan), think (pola pikir), act (perilaku), dan relate (pertalian) (Schmitt, 2011). Hal ini menjadi dasar penguatan untuk fokus pada pengalaman para wisatawan. 
Schmitt (2014) juga menyatakan bahwa experiential marketing adalah sebuah pendekatan dalam bidang pemasaran yang tidak hanya memberikan informasi atas sebuah produk, namun juga memberikan pengalaman yang melibatkan emosi konsumen. Experiential marketing ini merupakan pengembangan dari sistem pemasaran tradisional yang pada umumnya hanya terfokus pada fungsi suatu produk saja. Kelima kerangka dalam experiential marketing tersebut diharapkan mampu menumbuhkan kepuasan konsumen yang nantinya akan berdampak pada peningkatan minat beli ulang pelanggan. Hal tersebut dikarenakan kelima kerangka experiential marketing yang meliputi sense, feel, think, act, dan relate yang dikombinasikan untuk menciptakan sebuah pengalaman yang menyeluruh dan bertujuan untuk menciptakan kepuasan pelanggan. Kelima kerangka experiential marketing tersebut yakni:

1. Sense

Adanya rangsangan terhadap lima panca indera. Dari kelima indera yang dirangsang tersebut diharapkan mampu membawa pesan yang ingin disampaikan produsen secara terintegrasi.

2. Feel

Setelah melakukan rangsangan terhadap panca indera selanjutnya adalah mengelola perasaan konsumen. Produsen harus berupaya untuk menjaga mood serta emosi pelanggan. Produsen harus mengupayakan kenyamanan pelanggan untuk menjaga mood serta emosi pelanggan agar tetap baik. Sebab apabila perasaan atau feeling pelanggan dapat terkelola dengan baik, akan memicu pelanggan untuk dapat berpikir positif.

3. Think

Terdapaat dua pola berpikir yakni divergent-thinking atau pola pikir menyebar dan convergent-thinking atau pola pikir menyatu (Kartajaya, 2007). Pola pikir menyebar digunakan pada saat mencari beragam alternatif solusi yang mungkin dilakukan untuk memecahkan suatu masalah. Sementara pola pikir yang menyatu biasanya digunakan untuk mengevaluasi dan membuat pilihan atas alternatif-alternatif solusi yang ada.

4. Act

Pada tahapan act, tenaga pemasar berupaya untuk mengkombinasikan ketiga elemen experiential marketing sebelumnya yakni sense, feel, dan think menjadi sebuah aksi untuk menghasilkan memorable experience. Artinya pada tahap ini produsen mengikutsertakan konsumen dalam aksi nyata yang bertujuan untuk membentuk sebuah memorable experience dibenak konsumen.

5. Relate

Pada tahapan berikutnya produsen harus dapat menjaga hubungan yang baik dengan pelanggannya. Produsen harus berupaya membuat konsumen merasa senang, bangga, dan dapat diterima di komunitasnya.

Kepuasan pelanggan merupakan suatu hal yang sangat berharga demi mempertahankan keberadaan pelanggan. Dari keseluruhan kegiatan yang dilakukan oleh perusahaan, pada akhirnya akan bermuara pada nilai yang akan 
diberikan oleh pelanggan mengenai kepuasan yang dirasakannya. Menurut Tjiptono (2014), tidak ada satu pun ukuran tunggal terbaik mengenai kepuasan pelanggan yang disepakati secara universal. Meskipun demikian, ditengah beragamnya cara mengukur tingkat kepuasan pelanggan, terdapat kesamaan paling tidak dalam enam konsep inti mengenai objek pengukuran sebagai berikut:

1. Overall Customer Satisfaction

Cara yang paling sederhana untuk mengukur tingkat kepuasan pelanggan adalah langsung menanyakan kepada pelanggan seberapa puas mereka dengan produk atau jasa spesifik tertentu.

2. Dimention of Customer Satisfaction

Berbagai penelitian memilah tingkat kepuasan pelanggan ke dalam komponen-komponennya. Umumnya, proses semacam ini terdiri atas empat langkah. Pertama, mengidentifikasi dimensi-dimensi kunci kepuasan pelanggan. Kedua, meminta pelanggan menilai produk atau jasa perusahaan berdasarkan item-item spesifik, seperti kecepatan layanan, fasilitas layanan, atau keramahan staf layanan pelanggan. Ketiga, meminta pelanggan menilai produk atau jasa pesaing berdasarkan item-item spesifik yang sama, dan keempat, meminta para pelanggan untuk menentukan dimensi-dimensi yang menurut mereka paling penting dalam menilai tingkat kepuasan pelanggan keseluruhan.

3. Confirmation of Expectations

Dalam konsep ini, kepuasan tidak diukur langsung, namun disimpulkan berdasarkan kesesuaian/ketidaksesuaian antara harapan pelanggan dengan kinerja aktual produk perusahaan pada sejumlah atribut atau dimensi penting.

4. Repurchase Intention

Kepuasan pelanggan diukur secara behavioral dengan jalan menanyakan apakah pelanggan akan berbelanja atau menggunakan jasa perusahaan lagi.

5. Willingness to Recommend

Dalam kasus produk yang pembelian ulangnya relatif lama atau bahkan hanya terjadi satu kali pembelian (seperti pembelian mobil, broker rumah, asuransi jiwa, tur keliling dunia, dan sebagainya), kesediaan pelanggan untuk merekomendasikan produk kepada teman atau keluarganya menjadi ukuran yang penting untuk dianalisis dan ditindaklanjuti.

6. Customer Dissatisfaction

Beberapa macam aspek yang sering ditelaah guna mengetahui ketidakpuasan pelanggan, meliputi: a) komplain; b) retur atau pengembalian produk; c) biaya garansi; d) product recall (penarikan kembali produk dari pasar); e) gethok tular negatif; dan f) defections konsumen yang beralih ke pesaing.

\section{METODOLOGI}

Jenis penelitian ini adalah observasional dengan metode survey yang bersifat deskriptif dan analitik. Pendekatan penelitian yang digunakan adalah 
pendekatan kualitatif dan pendekatan kuantitatif dengan sifat penelitian adalah explanatory. Lokasi objek penelitian dilakukan di Kabupaten Belitung, tepatnya pada dua kecamatan yaitu Kecamantan Sijuk yang merupakan lokasi Desa Wisata Terong dan Kecamatan Tanjung Pandan yang merupakan wilayah bertetangga, dalam rangka pengembangan area objek penelitian dalam memenuhi jumlah sample minimum.

Populasi penelitian adalah wisatawan yang sedang berkunjung di Kabupaten Belitung, Provinsi Kepulauan Bangka Belitung selama proses pengumpulan data berlangsung, dengan beberapa asumsi. Berdasarkan publikasi data BPS Kabupaten Belitung nomor katalog 1102001.1902 pada Agustus 2019, terdapat 467.571 kunjungan wisatawan ke Kabupaten Belitung, 96,86 persen merupakan wisatawan nusantara dan 3,14 persen lainnya wisatawan mancanagera. Jumlah hotel/penginapan di Kabupaten Belitung sebesar 57 unit dengan jumlah kamar sebanyak 2166 kamar pada tahun 2018, yang didominasi sebesar 87.07 persen terpusat di Kecamatan Tanjung Pandan seperti terter pada tabel 4.2. Sedangkan Kecamatan Sijuk, lokasi wilayah administratif dari Desa Terong menyumbang sebesar 12,28 persen. Angka tersebut digunakan sebagai dasar perkiraan penentuan jumlah populasi penelitian berkisar sebesar 57.421 wisatawan. Melalui dasar nilai tersebut kemudian dilakukan asumsi dasar pada nilai prevalensi outcome sebesar 12 persen.

Tabel 1. Jumlah Hotel/Penginapan dan Kamar Menurut Kecamatan, 2018

\begin{tabular}{lrrrrr}
\hline Kecamatan & $\begin{array}{c}\text { Hotel } \\
\text { Bintang }\end{array}$ & $\begin{array}{c}\text { Hotel } \\
\text { Non } \\
\text { Bintang }\end{array}$ & Villa & Jumlah & Kamar \\
\hline Membalong & - & - & 2 & 2 & 14 \\
\hline Tajungpandan & 19 & 27 & - & 46 & 1.886 \\
\hline Badau & - & - & - & - & - \\
\hline Sijuk & 3 & 2 & 4 & 9 & 266 \\
\hline Selat Nasik & - & - & - & - & - \\
\hline \multicolumn{1}{c}{ Jumlah } & 22 & 29 & 6 & 57 & 2.166 \\
\hline
\end{tabular}

Sumber: BPS Kabupaten Belitung, Agustus 2019, diolah

Metode pengambilan sampel yang digunakan adalah dengan menggunakan nonprobability sampling dengan teknik sampling accidental sampling. Dikarenakan besar populasi tidak diketahui dengan langsung, maka penentuan jumlah sample penelitian diperoleh sebanyak 115 orang wisatawan, menggunakan pendekatan rumus Lemeshow (S. Lameshow dalam Murti, 2013) yang dituliskan sebagai berikut:

dimana:

$$
n \geq \frac{Z_{\propto / 2}^{2} P Q}{L^{2}}
$$

$\mathrm{n} \quad=$ ukuran sample minimum

$Z_{\alpha / 2}=$ nilai standar dari distribusi nilai $\alpha$, dalam penelitian ini digunakan nilai $\alpha / 2=10 \%$

$\mathrm{P} \quad=$ prevalensi outcome, dalam penelitian ini digunakan nilai 12 persen

$\mathrm{Q} \quad=1-\mathrm{P}$

$\mathrm{L} \quad=$ tingkat ketelitian, dalam penelitian ini digunakan sebesar 5 persen.

Dengan adanya experiential marketing yang dilakukan oleh rumah makan wisata maka diharapkan akan tercipta tingkat kepuasan wisatawan. Berdasarkan 
landasan tersebut, definisi operasional dari masing-masing variabel, indikatorindikator atau elemen-elemen yang akan diukur atau diobservasi dengan skala pengukuran skala likert dengan bobot 1 hingga bobot 5, dijelaskan dengan lebih rinci sebagai berikut:

1. Sense $\left(\mathrm{X}_{1}\right)$

Variabel ini meliputi pengalaman yang sifatnya dapat dirasakan oleh kelima indra manusia, dimana terdiri dari penglihatan (sight), pendengaran (sound), sentuhan (touch), penciuman (smell), dan perasa (taste).

2. Feel $\left(\mathrm{X}_{2}\right)$

Variabel ini meliputi pengalaman yang sifatnya menyentuh perasaan dan emosi pelanggan yang meliputi perasaan (feeling), emosi (emotion), dan suasana hati (mood).

3. Think $\left(\mathrm{X}_{3}\right)$

Variabel ini meliputi pengalaman yang mendorong pelanggan untuk berinteraksi secara kognitif atau secara kreatif dengan perusahaan, yang meliputi kejutan (surprise), intrik (intrique), provokasi (provocation).

4. $\operatorname{Act}\left(\mathrm{X}_{4}\right)$

Variabel ini meliputi pengalaman secara fisik, pola perilaku, dan gaya hidup jangka panjang, yang meliputi interaksi (interact), aksi (action), dan gaya hidup (lifestyle).

5. Relate $\left(\mathrm{X}_{5}\right)$

Variabel ini meliputi pengalaman yang sifatnya mengaitkan individu dengan sesuatu dengan sesuatu di luar dirinya, seperti pekerjaan, etnis, atau gaya hidup dan bahkan ruang lingkup sosial yang lebih luas. Variabel ini meliputi idealisasi diri (self idealization) dan kerjasama dengan pihak lain (others).

6. Kepuasan Pelanggan (Y)

Kepuasan para wisatawan merupakan keseluruhan sikap yang ditunjukkan oleh para wisatawan setelah mereka melakukan kunjungan wisata di Kabupaten Belitung.

\section{Uji Validitas dan Reliabilitas Instrumen}

Uji validitas dan realibilitas instrumen dalam penelitian ini dilakukan kepada 30 orang responden diluar daripada responden yang dijadikan sebagai sampel penelitian. Validitas data penelitian ditentukan oleh proses pengukuran yang akurat. Suatu instrumen pengukur dikatakan valid jika instrumen tersebut mengukur apa yang seharusnya diukur.

Untuk penelitian ini dilakukan uji korelasi item total yang juga disebut uji korelasi butir. Uji korelasi item total dilakukan untuk menguji validitas internal setiap item pertanyaan dalam kuesioner. Dalam pengujian ini skor item total dikorelasikan dengan skor total. Uji validitas instrumen dalam penelitian dengan cara mengkorelasikan setiap skor item masing-masing variabel dengan skor total variabel tersebut. Hasil perhitungan tersebut kemudian dibandingkan dengan titik kritis ( $\left.\mathrm{r}_{\text {tabel}}\right)$ pada taraf signifikan 5 persen. Jika nilai corrected item total correlation ( $\mathrm{r}_{\text {hitung }}$ ) $>\mathrm{r}_{\text {tabel }}$ dan nilainya positif, maka item atau butir pertanyaan pada setiap varibale penelitian dapat dinyatakan valid (Ghozali, 2011). 
Dengan menggunakan degree of freedom $(\mathrm{df})=28$ dan tingkat signifikansi untuk uji dua arah yaitu alpa $(\alpha)$ sebesar 0,05 maka diperoleh nilai $\mathrm{r}_{\text {tabel }}$ sebesar 0,361. Pengolahan data menghasilkan Tabel 2. berikut menunjukkan nilai rhitung dari setiap butir pertanyaan.

Tabel 2. Uji Validitas Instrumen

\begin{tabular}{|c|c|c|c|}
\hline No & Indikator & $\begin{array}{l}\text { Corrected Item } \\
\text { Total Correlation }\end{array}$ & Ket. \\
\hline \multirow[t]{6}{*}{1.} & Variabel Sense: & & \\
\hline & 1. Desain ruangan menarik & 0,785 & Valid \\
\hline & 2. Musik yang diputar menenangkan & 0,769 & Valid \\
\hline & 3. Rasa nyaman & 0,792 & Valid \\
\hline & 4. Aroma ruangan terasa segar & 0,757 & Valid \\
\hline & 5. Rasa makanan disajikan dengan baik & 0,767 & Valid \\
\hline \multirow[t]{4}{*}{2.} & Variabel Feel: & & \\
\hline & 1. Keramahan karyawan & 0,825 & Valid \\
\hline & 2. Pelayanan dilakukan cepat & 0,850 & Valid \\
\hline & 3. Suasana lingkungan santai & 0,809 & Valid \\
\hline \multirow[t]{4}{*}{3.} & Variabel Think: & & \\
\hline & 1. Promo iklan menarik & 0,756 & Valid \\
\hline & 2. Lokasi rumah makan strategis & 0,862 & Valid \\
\hline & 3. Terdapat paket pembelian ekonomis & 0,766 & Valid \\
\hline \multirow[t]{4}{*}{4.} & Variabel Act: & & \\
\hline & 1. Interaksi komunikatif antara pelayan dengan wisatawan & 0,813 & Valid \\
\hline & $\begin{array}{l}\text { 2. Pelayanan diberikan dapat disesuaikan dengan kebutuhan } \\
\text { wisatawan }\end{array}$ & 0,860 & Valid \\
\hline & $\begin{array}{l}\text { 3. Tempat yang tepat untuk berkumpul bersama keluarga atau } \\
\text { kerabat }\end{array}$ & 0,860 & Valid \\
\hline \multirow[t]{4}{*}{5.} & Variabel Relate: & & \\
\hline & $\begin{array}{l}\text { 1. Hubungan antara rumah makan dengan wisatawan dijalin } \\
\text { melalui komunikasi dua arah }\end{array}$ & 0,881 & Valid \\
\hline & 2. Memperoleh rekomendasi atau feedback dari pihak lain & 0,928 & Valid \\
\hline & 3. Menu disajikan sesuai dengan kebutuhan dan selera & 0,820 & Valid \\
\hline \multirow[t]{5}{*}{6.} & Variabel Kepuasan Pelanggan: & & \\
\hline & 1. Menu dikonsumsi tanpa rasa penyesalan & 0,902 & Valid \\
\hline & 2. Bersedia melakukan pembelian kembali & 0,829 & Valid \\
\hline & 3. Berinisiatif memberikan informasi kepada wisatawan lain & 0,862 & Valid \\
\hline & 4. Pelayanan sesuai dengan harapan wisatawan & 0,821 & Valid \\
\hline
\end{tabular}

Sumber: Hasil Penelitian, 2019 (IBM SPSS Statistics 22, diolah)

Dari hasil uji validitas instrumen seperti yang diperlihatkan pada Tabel 2. menunjukkan bahwa nilai rhitung dari setiap butir variabel pertanyaan $>$ nilai $\mathrm{r}_{\text {tabel }}$ $(0,361)$, yang artinya setiap butir variabel pertanyaan dinyatakan valid atau layak untuk dijadikan angket penelitian.

Reliabilitas adalah alat ukur berkenaan dengan derajad konsistensi dan stabilitas data yang dihasilkan dari proses pengumpulan data dengan menggunakan instrumen tersebut. Suatu kuesioner dikatakan reliabel atau handal jika jawaban dari responden terhadap pertanyaan adalah konsisten atau stabil dari waktu ke waktu.

Dalam penelitian ini akan dilakukan pengujian reliabilitas dengan menggunakan cara one shot. Alat test yang akan digunakan untuk pengujian ini adalah Koefisien Alpha Cronbach. Sekaran (dalam Zulganef, 2006) menyatakan bahwa suatu instrumen penelitian mengindikasikan memiliki reliabilitas yang memadai jika koefisien alpha cronbach lebih besar atau sama dengan 0,70. 
Tabel 3. Uji Reliabilitas Instrumen

\begin{tabular}{|c|c|c|c|}
\hline No & Indikator & $\begin{array}{l}\text { Cronbach's Alpha } \\
\text { if Item Deleted }\end{array}$ & Ket. \\
\hline \multirow[t]{6}{*}{1.} & Variabel Sense: & & \\
\hline & 1. Desain ruangan menarik & 0,833 & Riliabel \\
\hline & 2. Musik yang diputar menenangkan & 0,834 & Riliabel \\
\hline & 3. Rasa nyaman & 0,816 & Riliabel \\
\hline & 4. Aroma ruangan terasa segar & 0,809 & Riliabel \\
\hline & 5. Rasa makanan disajikan dengan baik & 0,818 & Riliabel \\
\hline \multirow[t]{4}{*}{2.} & Variabel Feel: & & \\
\hline & 1. Keramahan karyawan & 0,814 & Riliabel \\
\hline & 2. Pelayanan dilakukan cepat & 0,813 & Riliabel \\
\hline & 3. Suasana lingkungan santai & 0,820 & Riliabel \\
\hline \multirow[t]{4}{*}{3.} & Variabel Think: & & \\
\hline & 1. Promo iklan menarik & 0,832 & Riliabel \\
\hline & 2. Lokasi rumah makan strategis & 0,833 & Riliabel \\
\hline & 3. Terdapat paket pembelian ekonomis & 0,835 & Riliabel \\
\hline \multirow[t]{4}{*}{4.} & Variabel $A c t:$ & & \\
\hline & 1. Interaksi komunikatif antara pelayan dengan wisatawan & 0,802 & Riliabel \\
\hline & $\begin{array}{l}\text { 2. Pelayanan diberikan dapat disesuaikan dengan kebutuhan } \\
\text { wisatawan }\end{array}$ & 0,808 & Riliabel \\
\hline & $\begin{array}{l}\text { 3. Tempat yang tepat untuk berkumpul bersama keluarga atau } \\
\text { kerabat }\end{array}$ & 0,808 & Riliabel \\
\hline \multirow[t]{4}{*}{5.} & Variabel Relate: & & \\
\hline & $\begin{array}{l}\text { 1. Hubungan antara rumah makan dengan wisatawan dijalin } \\
\text { melalui komunikasi dua arah }\end{array}$ & 0,803 & Riliabel \\
\hline & 2. Memperoleh rekomendasi atau feedback dari pihak lain & 0,802 & Riliabel \\
\hline & 3. Menu disajikan sesuai dengan kebutuhan dan selera & 0,806 & Riliabel \\
\hline \multirow[t]{6}{*}{6.} & Variabel Kepuasan Pelanggan: & & \\
\hline & 1. Menu dikonsumsi tanpa rasa penyesalan & 0,807 & Riliabel \\
\hline & 2. Bersedia melakukan pembelian kembali & 0,801 & Riliabel \\
\hline & 3. Berinisiatif memberikan informasi kepada wisatawan lain & 0,807 & Riliabel \\
\hline & 4. Pelayanan sesuai dengan harapan wisatawan & 0,808 & Riliabel \\
\hline & Cronbach's Alpha & 0,823 & Riliabel \\
\hline
\end{tabular}

Sumber: Hasil Penelitian, 2019 (IBM SPSS Statistics 22, diolah)

Dari hasil uji reliabilitas instrumen seperti yang tertera pada Tabel 3. menunjukkan bahwa baik nilai koefisien alpha cronbach secara keseluruhan $(0,823)$ maupun setiap instrumen melebihi batas minimum reliabilitas yang digunakan dalam penelitian ini, yaitu 0,7 . Ini mengindikasikan bahwa secara keseluruhan semua instrumen variabel dalam penelitian ini adalah reliabel (konsisten).

\section{Uji Asumsi Klasik}

Model analisis data yang digunakan dalam penelitian ini adalah model regresi. Sebuah model yang baik adalah model dengan kesalahan peramalan yang seminimal mungkin. Oleh karena itu, sebelum model tersebut digunakan seharusnya dapat memenuhi beberapa asumsi yang biasa disebut asumsi klasik, asumsi-asumsi klasik yang harus dipenuhi adalah uji normalitas, uji multikolinearitas dan uji heteroskedastisitas.

Uji normalitas dilakukan untuk melihat apakah nilai residual yang dihasilkan dari model regresi terdistribusi secara normal atau tidak. Model regresi yang baik adalah yang memiliki nilai residual yang terdistribusi normal. Jadi uji normalitas bukan dilakukan pada masing-masing variabel tetapi pada nilai residualnya. Pada penelitian ini, uji normalitas akan dilakukan dengan pendekatan pengujian histrogram dan uji nilai Normal Probability Plot untuk mengetahui kenormalan residu dari model regresi. Dasar pengambilan keputusan yaitu: 
1. Jika data menyebar di sekitar diagonal dan mengikuti arah garis diagonal atau grafik histogramnya menunjukkan pola distribusi normal maka model regresi memenuhi asumsi normalitas.

2. Jika data menyebar jauh dari garis diagonal dan/atau tidak mengikuti arah garis diagonal atau grafik histogram tidak menunjukkan pola distribusi normal maka model regresi tidak memenuhi asumsi normalitas.
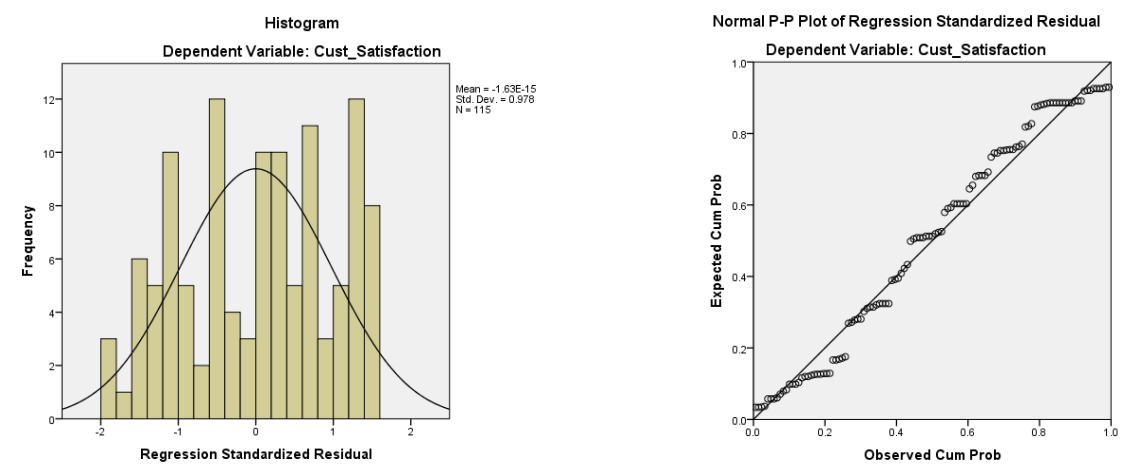

Gambar 3. Grafik Histogram Uji Normalitas dan Grafik Normal Probability Plot Sumber: Hasil Penelitian, 2019 (IBM SPSS Statistics 22)

Berdasarkan Gambar 3. tampilan grafik histogram maupun normal plot, terlihat bahwa data atau titik-titik menyebar disekitar grafik atau garis diagonal dan mengikuti arah grafik ataupun garis diagonal, maka dapat dinyatakan bahwa model regresi memenuhi asumsi normalitas.

Tabel 4. Uji Kolmogorov Smirnov Test

One-Sample Kolmogorov-Smirnov Test

\begin{tabular}{|c|c|c|}
\hline & & $\begin{array}{l}\text { Unstandardiz } \\
\text { ed Residual }\end{array}$ \\
\hline$N$ & & 115 \\
\hline \multirow[t]{2}{*}{ Normal Parameters ${ }^{a, b}$} & Mean & .0000000 \\
\hline & Std. Deviation & .81758278 \\
\hline \multirow[t]{3}{*}{ Most Extreme Differences } & Absolute & .097 \\
\hline & Positive & .094 \\
\hline & Negative & -.097 \\
\hline Test Statistic & & .097 \\
\hline Asymp. Sig. (2-tailed) & & $.010^{\mathrm{c}}$ \\
\hline
\end{tabular}

Sumber: Hasil Penelitian, 2019 (IBM SPSS Statistics 22)

Ghozali (2011) menyatakan bahwa ada dua cara untuk mendeteksi apakah residual berdistribusi normal atau tidak yaitu dengan analisis grafik dan uji statistik. Oleh karena itu, untuk memperkuat hasil ini, selain analisis grafik peneliti juga menggunakan uji statistik yaitu uji Kolmogorov Smirnov (K-S) yang ditujukan untuk menguji normalitas residual data. Berdasarkan Tabel 4. dapat dilakukan analisis berupa:

1. Test Statistic Kolmogorov Smirnov menunjukkan nilai Zhitung sebesar 0,097 dibandingkan terhadap nilai $Z_{\text {tabel }}$ dengan memilih level of 
significance $\alpha=0,05$ dan dua ujung wilayah kritis (the two-sided critical region) pada tabel distribusi normal standar diketahui sebesar

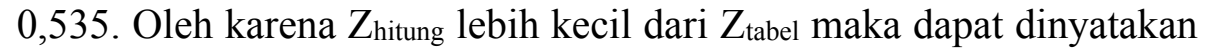
data residual berdistribusi normal.

2. Asymptotic significance 2 tailed merupakan pengujian nilai probability untuk memastikan bahwa distribusi teramati tidak akan menyimpang secara signifikan dari distribusi yang diharapkan di kedua ujung two tailed distribution. Diketahui juga bahwa pengujian ini dilakukan dengan metode lilliefors yaitu metoda yang menggunakan data dasar yang belum diolah dalam tabel distribusi frekuensi. Data ditransformasikan dalam nilai $\mathrm{Z}$ untuk dapat dihitung luasan kurva normal sebagai probabilitas komulatif normal. Probabilitas tersebut dicari bedanya dengan probabilitas komultaif empiris. Beda terbesar dibanding dengan tabel lilliefors pada tabel nilai quantil statistik lilliefors distribusi normal. Nilai | $\mathrm{F}(\mathrm{x})-\mathrm{S}(\mathrm{x})$ | diperoleh sebesar 0,010 dibandingkan terhadap nilai tabel lilliefors dengan $\alpha=0,05$ dan $\mathrm{df}=115$ diketahui sebesar 0,082 . Oleh karena nilai | F(x)-S(x) | lebih kecil dari nilai tabel lilliefors maka dapat dinyatakan data residual berdistribusi normal.

Uji multikolinearitas adalah untuk melihat ada atau tidaknya korelasi yang tinggi antara variabel-variabel independent dalam suatu model regresi linear berganda. Jika ada korelasi yang tinggi diantara variabel-variabel independent tersebut maka hubungan antara variabel independent terhadap variabel dependent menjadi terganggu. Menurut Bhuono (2005) mengemukakan bahwa deteksi multikolineritas pada statu model dapat dilihat dari beberapa hal, antara lain:

1. Jika nilai Variance Inflation Factor (VIF) tidak lebih dari 10 dan nilai Tolerance tidak kurang dari 0,1 maka model dapat dikatakan terbebas dari multikolineritas. Nilai Tolerance yang rendah sama dengan nilai VIF tinggi karena VIF $=1 /$ Tolerance.

Tabel 5. Uji Multikolinearitas

Coefficients $^{a}$

\begin{tabular}{|c|c|c|c|c|c|c|c|c|}
\hline \multirow{2}{*}{\multicolumn{2}{|c|}{ Model }} & \multicolumn{2}{|c|}{ Unstandardized Coefficients } & \multirow{2}{*}{$\begin{array}{c}\begin{array}{c}\text { Standardized } \\
\text { Coefficients }\end{array} \\
\text { Beta } \\
\end{array}$} & \multirow[b]{2}{*}{$\mathrm{t}$} & \multirow[b]{2}{*}{ Sig. } & \multicolumn{2}{|c|}{ Collinearity Statistics } \\
\hline & & $B$ & Std. Error & & & & Tolerance & VIF \\
\hline \multirow[t]{6}{*}{1} & (Constant) & 2.859 & 2.105 & & 1.359 & .177 & & \\
\hline & Sense & .007 & .127 & .002 & .054 & .957 & .766 & 1.306 \\
\hline & Feel & .406 & .082 & .405 & 4.974 & .000 & .243 & 4.118 \\
\hline & Think & .023 & .140 & .009 & .162 & .872 & .528 & 1.894 \\
\hline & Act & .285 & .074 & .226 & 3.834 & .000 & .461 & 2.169 \\
\hline & Relate & .417 & .097 & .368 & 4.284 & .000 & .218 & 4.597 \\
\hline
\end{tabular}

a. Dependent Variable: Cust_Satisfaction

Sumber: Hasil Penelitian, 2019 (IBM SPSS Statistics 22)

Berdasarkan pada Tabel 5. menunjukkan bahwa nilai Tolerance tidak kurang dari 0,10 yang berarti tidak ada korelasi antar variabel independent. Hasil perhitungan nilai Variance Inflation Factor (VIF) juga menunjukkan hal yang sama tidak ada satu variabel independent yang memiliki nilai VIF lebih dari 10. Jadi dapat disimpulkan bahwa 
tidak ada multikolonieritas antar variabel independent dalam model regresi pada penelitian ini.

2. Jika nilai koefisien antar masing-masing variabel independent kurang dari 0,70 maka model dapat dikatakan bebas dari asumsi klasik multikolineritas. Jika lebih dari 0,7 maka diasumsikan terjadi korelasi yang sangat kuat antar variabel independent sehingga terjadi multikolineritas.

Tabel 6. Koefisen Korelasi Uji Multikolinearitas Coefficient Correlationsa

\begin{tabular}{|lll|r|r|r|r|r|}
\hline Model & & & \multicolumn{1}{c|}{ Relate } & \multicolumn{1}{c|}{ Sense } & \multicolumn{1}{c|}{ Think } & \multicolumn{1}{c|}{ Act } & \multicolumn{1}{c|}{ Feel } \\
\hline 1 & Correlations & Relate & 1.000 & .034 & -.012 & -.512 & -.669 \\
& & Sense & .034 & 1.000 & -.462 & -.114 & -.208 \\
& & Think & -.012 & -.462 & 1.000 & -.002 & .421 \\
& Act & -.512 & -.114 & -.002 & 1.000 & .021 \\
& & Feel & -.669 & -.208 & .421 & .021 & 1.000 \\
\hline
\end{tabular}

a. Dependent Variable: Cust_Satisfaction

Sumber: Hasil Penelitian, 2019 (IBM SPSS Statistics 22)

Berdasarkan pada Tabel 6. menunjukkan bahwa antar variabel independent memiliki nilai korelasi kurang dari 0,70 yang berarti tidak ada korelasi antar variabel independent. Jadi dapat disimpulkan bahwa tidak ada multikolonieritas antar variabel independent dalam model regresi pada penelitian ini.

Uji heteroskedastisitas bertujuan menguji apakah dalam model regresi terjadi ketidaksamaan variance dari residual satu pengamatan ke pengamatan yang lain. Jika variance dari residual satu pengamatan ke pengamatan lain tetap, maka disebut homoskedastisitas dan jika berbeda disebut heteroskedastisitas.

Menurut Gujarati (2012) untuk menguji ada tidaknya heteroskedastisitas digunakan uji rank spearman yaitu dengan mengkorelasikan variabel independen terhadap nilai absolut dari residual (error). Bila signifikansi hasil korelasi lebih kecil dari 0,05 maka persamaan regresi tersebut mengandung heteroskedastisitas dan sebaliknya berarti non heteroskedastisitas atau homoskedastisitas.

Tabel 7. Uji Heteroskedastisitas dengan Uji Rank Spearmen

\begin{tabular}{|c|c|c|c|c|c|c|c|c|}
\hline \multicolumn{9}{|c|}{ Correlations } \\
\hline & & & Sense & Feel & Think & Act & Relate & $\begin{array}{l}\text { Unstandardiz } \\
\text { ed Residual }\end{array}$ \\
\hline \multirow[t]{18}{*}{ Spearman's rho } & \multirow[t]{3}{*}{ Sense } & Correlation Coefficient & 1.000 & $.686^{\mathrm{n}}$ & $.675^{\mathrm{nx}}$ & $.723^{\mathrm{kn}}$ & .047 & -.067 \\
\hline & & Sig. (2-tailed) & & .000 & .000 & .000 & .622 & .479 \\
\hline & & $\mathrm{N}$ & 174 & 174 & 174 & 174 & 115 & 115 \\
\hline & \multirow[t]{3}{*}{ Feel } & Correlation Coefficient & $.686^{\mathrm{Nx}}$ & 1.000 & $.422^{\mathrm{nx}}$ & $.863^{\mathrm{Nx}}$ & $.864^{\mathrm{kx}}$ & .026 \\
\hline & & Sig. (2-tailed) & .000 & & .000 & .000 & .000 & .783 \\
\hline & & $N$ & 174 & 174 & 174 & 174 & 115 & 115 \\
\hline & \multirow[t]{3}{*}{ Think } & Correlation Coefficient & $.675^{\mathrm{nx}}$ & $.422^{\mathrm{nn}}$ & 1.000 & $.510^{\mathrm{kx}}$ & $-.476^{1 \times}$ & -.040 \\
\hline & & Sig. (2-tailed) & .000 & .000 & & .000 & .000 & .674 \\
\hline & & $N$ & 174 & 174 & 174 & 174 & 115 & 115 \\
\hline & \multirow[t]{3}{*}{ Act } & Correlation Coefficient & $.723^{\mathrm{nn}}$ & $.863^{\mathrm{nn}}$ & $.510^{\mathrm{nk}}$ & 1.000 & $.724^{\mathrm{nx}}$ & .042 \\
\hline & & Sig. (2-tailed) & .000 & .000 & .000 & & .000 & .658 \\
\hline & & $\mathrm{N}$ & 174 & 174 & 174 & 174 & 115 & 115 \\
\hline & \multirow[t]{3}{*}{ Relate } & Correlation Coefficient & .047 & $.864^{\mathrm{nn}}$ & $-.476^{\mathrm{Nx}}$ & $.724^{\mathrm{Nm}}$ & 1.000 & .053 \\
\hline & & Sig. (2-tailed) & .622 & .000 & .000 & .000 & & .572 \\
\hline & & $N$ & 115 & 115 & 115 & 115 & 115 & 115 \\
\hline & \multirow[t]{3}{*}{ Unstandardized Residual } & Correlation Coefficient & -.067 & .026 & -.040 & .042 & .053 & 1.000 \\
\hline & & Sig. (2-tailed) & .479 & .783 & .674 & .658 & .572 & \\
\hline & & $N$ & 115 & 115 & 115 & 115 & 115 & 115 \\
\hline
\end{tabular}

**. Correlation is significant at the 0.01 level (2-tailed).

Sumber: Hasil Penelitian, 2019 (IBM SPSS Statistics 22) 
Berdasarkan Tabel 7. menunjukkan bahwa tidak ada satupun variabel independent yang signifikan secara statistik berkorelasi terhadap nilai residual. Hal ini terlihat dari probabilitas signifikansinya (Sig.) diatas tingkat kepercayaan 5 persen. Jadi dapat disimpulkan bahwa model regresi dalam penelitian ini tidak terjadi adanya heteroskedastisitas.

\section{Analisis Regresi Linier Berganda}

Sehubungan bahwa penelitian ini adalah untuk mengkaji seberapa jauh sebuah variabel dependent yaitu dalam hal ini adalah kepuasan pelanggan yang dipengaruhi oleh beberapa variabel independent yakni dalam hal ini 5 (lima) faktor experiential marketing yang terdiri dari sense, feel, act, think dan relate maka model analisis yang akan digunakan untuk mengkaji hubungan ini adalah dengan model analisis regresi linier berganda (multiple linear regression). Dalam analisis regresi linier berganda akan dikembangkan sebuah persamaan regresi yaitu suatu formula yang mencari nilai variabel dependent dari nilai variabel independent yang diketahui, yaitu:

dimana:

$$
\mathrm{Y}=\mathrm{a}+\mathrm{b}_{1} \mathrm{X}_{1}+\mathrm{b}_{2} \mathrm{X}_{2}+\mathrm{b}_{3} \mathrm{X}_{3}+\mathrm{b}_{4} \mathrm{X}_{4}+\mathrm{b}_{5} \mathrm{X}_{5}+\mathrm{e}
$$

$$
\begin{array}{ll}
\mathrm{Y} & =\text { Kepuasan Pelanggan } \\
\mathrm{X}_{1} & =\text { Sense } \\
\mathrm{X}_{2} & =\text { Feel } \\
\mathrm{X}_{3} & =\text { Act } \\
\mathrm{X}_{4} & =\text { Think } \\
\mathrm{X}_{5} & =\text { Relate } \\
\mathrm{e} & =\text { epsilon atau variabel yang tidak diteliti }
\end{array}
$$

Analisis regresi linier berganda bertujuan untuk mengetahui seberapa besar pengaruh variabel independent menyebabkan terjadinya variabel dependent. Analisis data penelitian dilakukan pada tingkat kepercayaan (confidence of interval) sebesar 95 persen dengan tingkat toleransi kesalahan (alpha) sebesar 5 persen.

\section{Uji F (uji simultan)}

Uji statisik F pada dasarnya menunjukkan apakah semua variabel independent atau bebas yang dimasukkan dalam model mempunyai pengaruh secara bersama-sama terhadap variabel dependent atau terikat. Didalam uji ini juga berarti bahwa semua variabel independent secara simultan merupakan penjelas yang signifikan terhadap variabel dependent (Ghozali, 2011). Uji F bertujuan untuk mengetahui pengaruh variabel independent secara serempak terhadap variabel dependent dengan tingkat keyakinan 95 persen ( $\alpha=5$ persen). Kriteria pengujian hipotesa uji $\mathrm{F}$ sebagai berikut:

1. $\mathrm{H}_{0}: \mathrm{X}_{1}, \mathrm{X}_{2}, \mathrm{X}_{3}, \mathrm{X}_{4}, \mathrm{X}_{5}=0$

Experiential marketing yang terdiri dari sense, feel, act, think dan relate secara serempak tidak berpengaruh terhadap tingkat kepuasan wisatawan pada rumah makan wisata di Kabupaten Belitung.

2. $\mathrm{H}_{\mathrm{a}}: \mathrm{X}_{1}, \mathrm{X}_{2}, \mathrm{X}_{3}, \mathrm{X}_{4}, \mathrm{X}_{5} \neq 0$

Experiential marketing yang terdiri dari sense, feel, act, think dan relate secara serempak berpengaruh terhadap tingkat kepuasan wisatawan pada rumah makan wisata di Kabupaten Belitung. 
Jika Fhitung $<\mathrm{F}_{\text {tabel, }}$ maka $\mathrm{H}_{0}$ diterima dan $\mathrm{H}_{\mathrm{a}}$ ditolak, dan jika $\mathrm{F}_{\text {hitung }}>\mathrm{F}_{\text {tabel, }}$ maka $\mathrm{H}_{0}$ ditolak dan $\mathrm{H}_{\mathrm{a}}$ diterima.

\section{Uji t (uji parsial)}

Uji statistik t pada dasarnya menunjukkan seberapa jauh pengaruh satu variabel penjelas atau independent secara individual dalam menerangkan variasi variabel dependent (Ghozali, 2011). Uji t dalam peneilitian ini dilakukan untuk menunjukan apakah empat variabel independent sense, feel, act, think dan relate mempunyai pengaruh yang signifikan terhadap variabel dependent tingkat kepuasan pelanggan. Kriteria pengujian hipotesa uji parsial sebagai berikut:

1. $\mathrm{H}_{0}: \mathrm{b}_{\mathrm{i}}=0$

Experiential marketing yang terdiri dari sense, feel, act, think dan relate secara parsial tidak berpengaruh terhadap Kepuasan Wisatawan pada rumah makan wisata di Kabupaten Belitung.

2. $\mathrm{H}_{\mathrm{a}}: \mathrm{b}_{\mathrm{i}} \neq 0$

Experiential marketing yang terdiri dari sense, feel, act, think dan relate secara parsial berpengaruh terhadap Kepuasan Wisatawan pada rumah makan wisata di Kabupaten Belitung.

Jika thitung $<t_{\text {tabel, }}$ maka $\mathrm{H}_{0}$ diterima dan $\mathrm{H}_{\mathrm{a}}$ ditolak, dan jika thitung $>t_{\text {tabel, }}$ maka $\mathrm{H}_{0}$ ditolak dan $\mathrm{H}_{\mathrm{a}}$ diterima.

\section{Koefisien determinasi $\left(\mathbf{R}^{2}\right)$}

Koefisien determinasi adalah untuk mengukur kemampuan variabel independent yang menjelaskan pengaruhnya terhadap variabel dependent. Dimana untuk mempertimbangkan kenyataan bahwa besaran derajat kebebasan menurun sehubungan dengan bertambahnya variabel bebas atau variabel penjelas di dalam regresi, juga dihitung $\mathrm{R}^{2}$ yang disesuaikan dengan adjusted $\mathrm{R}^{2}$ sebagai berikut:

Dimana:

$$
\text { Adjusted } R^{2}=1-1\left(1-R^{2}\right)\left[\frac{n-1}{n-k}\right]
$$

$\mathrm{n}=$ jumlah observasi atau sampel data

$\mathrm{k}=$ jumlah parameter atau koefisien yang diestimsi.

\section{HASIL DAN PEMBAHASAN}

\section{Gambaran Umum Kabupaten Belitung}

Secara astronomis, Belitung terletak antara 107o08' BT sampai 107o58' BT dan 02o30' LS sampai 03o15' LS dengan luas daratan seluruhnya 229.369 hektar. Kabupaten Belitung merupakan bagian dari wilayah Provinsi Kepulauan Bangka Belitung, dan terdiri dari sekitar seratus buah pulau besar dan kecil. Pada peta dunia Pulau Belitung dikenal dengan nama Billitonit yang bergaris tengah Timur-Barat $+79 \mathrm{~km}$ dan garis tengah Utara-Selatan $+77 \mathrm{~km}$. Dengan batas wilayah sebelah utara berbatasan dengan Laut Cina Selatan, sebelah timur berbatasan dengan Kabupaten Belitung Timur, sebelah Selatan berbatasan dengan laut Jawa, dan sebelah Barat berbatasan dengan Selat Gaspar. Pulau yang terbesar di Kabupaten Belitung adalah Pulau Belitung. Disamping itu, masih ada pulau besar lainnya, seperti: Pulau Seliu, Pulau Mendanau, dan Pulau Nadu. Kabupaten Belitung terdiri dari lima kecamatan, yaitu Membalong, Tanjungpandan, Sijuk, Badau, dan Selat Nasik. 
Kabupaten Belitung dengan ibu kota kabupaten berada di Tanjungpandan, merupakan wilayah pengembangan angansektor perdagangan dan jasa, pertanian, pariwisata, industri pengolahan dan perikanan laut. Kabupaten Belitung terdiri dari 42 buah desa dan 7 Kelurahan yang tersebar di lima kecamatan. Penduduk Kabupaten Belitung berdasarkan proyeksi penduduk tahun 2018 sebanyak 186.155 jiwa, terdiri atas 96.456 jiwa penduduk laki-laki dan 89.699 jiwa penduduk perempuan, dengan laju pertumbuhan 2018 sebesar 2,05 persen.

Tabel 8. Geografis dan Kependudukan Kabupaten Belitung

\begin{tabular}{clcccccc} 
No & Kecamatan & $\begin{array}{c}\text { Luas } \\
\text { Wilayah } \\
\left(\mathrm{km}^{2}\right)\end{array}$ & $\begin{array}{c}\text { Jumlah } \\
\text { Pulau }\end{array}$ & Kelurahan & Desa & $\begin{array}{c}\text { Jumlah } \\
\text { Penduduk }\end{array}$ & $\begin{array}{c}\text { Hotel / } \\
\text { Penginapan }\end{array}$ \\
\hline 1 & Membalong & 909,55 & 35 & - & 12 & 28.772 & 2 \\
\hline 2 & Tanjungpandan & 378,45 & 17 & 7 & 9 & 103.594 & 46 \\
\hline 3 & Sijuk & 458,20 & 55 & - & 7 & 15.522 & 9 \\
\hline 4 & Badau & 413,99 & 18 & - & 10 & 31.998 & - \\
\hline 5 & Selat Nasik & 133,50 & 38 & - & 4 & 6.269 & - \\
\hline & & $2.293,69$ & 163 & 7 & 42 & 186.155 & 57 \\
\hline
\end{tabular}

Sumber: Katalog Kabupaten Belitung dalam Angka (BPS Kab.Belitung 2019, diolah)

Kabupaten Belitung memiliki luas wilayah terbesar sebesar 39,65 persen berada di Kecamatan Membalong, jumlah pulau terbanyak berada di Kecamatan Sijuk dengan porsi 33,74 persen, sebesar 55,65 persen penduduknya terpusat di Kecamatan Tanjungpandan, begitu juga dengan jumlah hotel terpusat berada di Kecamatan Tanjungpandan dengan porsi sebesar 80,7 persen.

Kecamatan Sijuk merupakan bagian dari wilayah Kabupaten Belitung yang juga merupakan wilayah kepulauan yang terdiri dari 17 buah pulau besar dan kecil. Kecamatan Sijuk kaya dengan pantai, dimana ada pantai yang indah yang juga kaya akan hasil ikan, seperti Pantai Tanjung Kelayang, Tanjung Tinggi, Pendaunan dan lainnya. Pantai-pantai tesebut merupakan objek wisata yang sedang dikembangkan di Kabupaten Belitung.

Pusat Pemerintahan Kecamatan Sijuk adalah di Desa Sijuk dengan luas seluruhnya 458,2 hektar terletak di Pulau Belitung. Penduduk di Kecamatan Sijuk terdiri dari 15.870 laki-laki atau 51,78 persen dan 14.776 perempuan atau 48,22 persen. Kepadatan penduduk, di Kecamatan Sijuk mengalami kenaikan dari 67 jiwa per $\mathrm{km}^{2}$ di tahun 2016 menjadi 68 jiwa per $\mathrm{km}^{2}$ di tahun 2017. Diantara 10 desa yang ada di Kecamatan Sijuk, ada 4 desa yang kepadatan penduduknya lebih dari 100 jiwa per $\mathrm{Km}^{2}$ yaitu Desa Tanjung Tinggi, Tanjung Binga, Batu Itam, dan Desa Terong.

Tabel 9. Geografis dan Kependudukan Kecamatan Sijuk Tahun 2017

\begin{tabular}{rlrrrr} 
No & \multicolumn{1}{c}{ Desa } & $\begin{array}{c}\text { Luas } \\
\text { Wilayah } \\
\left(\mathrm{km}^{2}\right)\end{array}$ & $\begin{array}{c}\text { Jumlah } \\
\text { Penduduk }\end{array}$ & $\begin{array}{c}\text { Jumlah } \\
\text { Akomodasi }\end{array}$ & $\begin{array}{c}\text { Jumlah } \\
\text { Restoran / } \\
\text { Rumah Makan }\end{array}$ \\
\hline 1 & Batu Itam & 14,00 & 2,458 & - & 4 \\
\hline 2 & Terong & 16,00 & 2.508 & - & 4 \\
\hline 3 & Air Seru & 61,80 & 5.518 & - & 16 \\
\hline 4 & Air Selumar & 93,50 & 2.857 & 1 & 28 \\
\hline 5 & Tanjung Binga & 21,80 & 6.620 & 2 & 6 \\
\hline 6 & Keciput & 24,65 & 2.498 & 1 & 4 \\
\hline 7 & Sijuk & 74,00 & 3.074 & 1 & 14 \\
\hline 8 & Sungai Padang & 69,70 & 2.274 & - & \\
\hline 9 & Tanjung Tinggi & 2,55 & 1.043 & 1 & \\
\hline
\end{tabular}




\begin{tabular}{|c|c|c|c|c|}
\hline $10 \quad$ Pelepak Pute & 74,00 & 1.796 & - & 4 \\
\hline & 452,00 & 30.646 & 6 & 103 \\
\hline
\end{tabular}

Sumber: Katalog Kec. Sijuk dalam Angka (BPS Kab. Belitung 2018, diolah)

Desa Terong sebagai lokus utama penelitian berlokasi di Kecamatan Terong, dengan tingkat kepadatan penduduk sebesar 157 jiwa per $\mathrm{km}^{2}$. Desa Terong dipersiapkan sebagai salah satu desa wisata di Kabupaten Belitung. Desa Terong didukung oleh jumlah pulau yang berada di Kecamatan Sijuk, dengan jumlah terbanyak di Kabupaten Belitung sebesar 55 pulau. Kesiapan penduduk desa terhadap sadar wisata juga terlihat di daerah ini melalui beberapa hal seperti keramahtamahan terhadap wisatawan, ketersediaan homestay dan keterbukaan informasi kepada wisatawan.

\section{Analisis Deskriptif Karakteristik Responden}

Pada penelitian ini, responden dibagi menjadi lima karakteristik yaitu berdasarkan usia, jenis kelamin, pekerjaan, asal negara, dan lama menginap.

Tabel 10. Karakteristik Responden

\begin{tabular}{|c|c|c|}
\hline No & Karakteristik Responden & Satuan / Value \\
\hline 1. & Interval Usia & $\begin{array}{l}1=21-30 \text { tahun } \\
2=31-40 \text { tahun } \\
3=41-50 \text { tahun } \\
4=>50 \text { tahun }\end{array}$ \\
\hline 2. & Jenis Kelamin & $\begin{array}{l}1=\text { Pria } \\
2=\text { Wanita }\end{array}$ \\
\hline 3. & Pekerjaan & $\begin{array}{l}1=\text { Swasta } \\
2=\text { Negeri } \\
3=\text { Pensiunan }\end{array}$ \\
\hline 4. & Asal Negara & $\begin{array}{l}1=\text { Indonesia } \\
2=\text { China } \\
3=\text { Malaysia } \\
4=\text { Singapura } \\
5=\text { Lainnya }\end{array}$ \\
\hline 5. & Lama Menginap & $\begin{array}{l}1=1-2 \text { hari } \\
2=3-4 \text { hari } \\
3=4-5 \text { hari } \\
4=>5 \text { hari }\end{array}$ \\
\hline
\end{tabular}

Tabel 11. Statistik Deskriptif Responden

\begin{tabular}{|l|r|r|r|r|r|}
\hline & N & Minimum & Maximum & Mean & Std. Deviation \\
\hline Usia & 115 & 26 & 56 & 37.20 & 8.576 \\
Interval Usia & 115 & 1 & 4 & 2.13 & .941 \\
Jenis Kelamin & 115 & 1 & 2 & 1.62 & .488 \\
Pekerjaan & 115 & 1 & 3 & 1.29 & .604 \\
Asal Negara & 115 & 1 & 5 & 1.35 & .879 \\
Lama Menginap & 115 & 1 & 4 & 1.37 & .628 \\
Valid N (listwise) & 115 & & & & \\
\hline
\end{tabular}

Sumber: Hasil Penelitian, 2019 (IBM SPSS Statistics 22)

Berdasarkan analisis, dapat diperoleh beberapa kesimpulan mendasar dari para responden yaitu: 
1. Interval usia responden berada di 26-56 tahun, dengan rata-rata usia adalah 37 tahun.

2. Dominan responden berada di interval usia 31-40 tahun sebesar 44,3 persen, dimana interval usia 31-50 berjumlah 71,3 persen.

3. Responden didominasi oleh wisatawan wanita sebesar 61,7 persen.

4. Sektor swasta merupakan dominasi pekerjaan para wisatawan sebesar 79,1 persen.

5. Wisatawan didominasi berasal dari Indonesia sebesar 83,5 persen disusul responden dari Malaysia 6,1 persen, China 5,2 persen dan 3,5 persen responden berasal dari Singapura.

6. Sebesar 69,6 persen wisatawan menginap selama 1-2 hari menginap dan 24,3 persen responden menginap selama 3-4 hari, mengindikasikan bahwa 93,9 persen responden melakukan kegiatan wisata antaa 1 hingga 4 hari di Belitung.

\section{Uji Signifikansi Simultan (Uji Statistik F)}

Untuk menguji pengaruh experiential marketing yang terdiri dari komitmen, empati, timbal balik, dan kepercayaan secara serempak terhadap tingkat kepuasan wisatawan di Kabupaten Belitung digunakan uji Statistik F (uji F). Apabila nilai $F_{\text {hitung }}>$ nilai $F_{\text {tabel, }}$, maka Ho ditolak dan Ha diterima. Sebaliknya apabila nilai $F_{\text {hitung }}<$ nilai $F_{\text {tabel, }}$ maka Ho diterima dan Ha ditolak.

Berdasarkan Tabel 5.15. berikut akan menunjukkan bahwa nilai $\mathrm{F}_{\text {hitung }}$ sebesar 102,643 dan tingkat signifikansinya sebesar 0,000 sedangkan dengan menggunakan tingkat kepercayaan (confidence interval) 95 persen atau $\alpha=0,05$, $\mathrm{df} 1=5, \mathrm{df} 2=110$ diperoleh nilai $\mathrm{F}_{\text {tabel }}$ sebesar 2,30. Dengan membandingkan nilai $F_{\text {hitung }}$ dan $F_{\text {tabel, }}$ diketahui bahwa $F_{\text {hitung }}(102,643)>F_{\text {tabel }}(2,30)$ dan nilai Sig. $(0,000)<\alpha(0,05)$, bermakna bahwa Ho ditolak, dan Ha diterima, yang artinya secara serempak variabel experiential marketing yang terdiri dari komitmen, empati, timbal balik dan kepercayaan berpengaruh positif dan sangat nyata (high significant) terhadap tingkat kepuasan wisatawan di Kabupaten Belitung.

Tabel 12. Uji Siginifikansi Simultan (Uji Statistik F)

ANOVA $^{a}$

\begin{tabular}{|c|c|c|c|c|c|c|}
\hline \multicolumn{2}{|c|}{ Model } & $\begin{array}{c}\text { Sum of } \\
\text { Squares }\end{array}$ & df & Mean Square & $\mathrm{F}$ & Sig. \\
\hline \multirow[t]{3}{*}{1} & Regression & 358.789 & 5 & 71.758 & 102.643 & $.000^{\mathrm{b}}$ \\
\hline & Residual & 76.202 & 109 & .699 & & \\
\hline & Total & 434.991 & 114 & & & \\
\hline
\end{tabular}

a. Dependent Variable: Cust_Satisfaction

b. Predictors: (Constant), Relate, Sense, Think, Act, Feel

Sumber: Hasil Penelitian, 2019 (IBM SPSS Statistics 22, diolah)

Hasil uji signifikansi simultan menunjukkan bahwa dalam penelitian ini experiential marketing yang terdiri dari variabel sense, feel, act, think dan relate secara serempak berpengaruh signifikan terhadap tingkat kepuasan wisatawan di Kabupaten Belitung.

\section{Uji Signifikansi Parameter Individual (Uji Statistik t)}

Untuk menguji pengaruh experiential marketing yang terdiri dari komitmen, empati, timbal balik dan kepercayaan secara parsial terhadap tingkat 
kepuasan wisatawan di Kabupaten Belitung, digunakan uji Statistik t (uji t). Apabila nilai thitung $>$ nilai tabel, maka Ho ditolak dan Ha diterima. Sebaliknya apabila nilai thitung $<$ nilai tabel, maka Ho diterima dan Ha ditolak.

Tabel 13. Uji Siginifikansi Parameter Individual (Uji Statistik t)

Coefficients $^{a}$

\begin{tabular}{|c|c|c|c|c|c|c|}
\hline \multirow{2}{*}{\multicolumn{2}{|c|}{ Model }} & \multicolumn{2}{|c|}{ Unstandardized Coefficients } & \multirow{2}{*}{$\begin{array}{c}\begin{array}{c}\text { Standardized } \\
\text { Coefficients }\end{array} \\
\text { Beta } \\
\end{array}$} & \multirow[b]{2}{*}{$\mathrm{t}$} & \multirow[b]{2}{*}{ Sig. } \\
\hline & & $\mathrm{B}$ & Std. Error & & & \\
\hline \multirow[t]{6}{*}{1} & (Constant) & 2.859 & 2.105 & & 1.359 & .177 \\
\hline & Sense & .007 & .127 & .002 & .054 & .957 \\
\hline & Feel & .406 & .082 & .405 & 4.974 & .000 \\
\hline & Think & .023 & .140 & .009 & .162 & .872 \\
\hline & Act & .285 & .074 & .226 & 3.834 & .000 \\
\hline & Relate & .417 & .097 & .368 & 4.284 & .000 \\
\hline
\end{tabular}

a. Dependent Variable: Cust_Satisfaction

Sumber: Hasil Penelitian, 2019 (IBM SPSS Statistics 22 dan diolah)

Berdasarkan Tabel 13. diperoleh model persamaan regresi linier dalam penelitian ini yaitu:

$$
\mathrm{Y}=2,859+0,007 \mathrm{X}_{1}+0,406 \mathrm{X}_{2}+0,023 \mathrm{X}_{3}+0,285 \mathrm{X}_{4}+0,417 \mathrm{X}_{5}
$$

Bermakna:

1. Berdasarkan persamaan diatas, jika $X_{1}, X_{2}, X_{3}, X_{4}, X_{5}=0$, maka nilai $Y$ sebesar 2,859. Artinya jika tingkat kepuasan pelanggan tidak dipengaruhi oleh kelima variabel sense, feel, act, think dan relate, maka tingkat kepuasan wisatawan adalah 2,859 satuan.

2. Nilai konstanta sebesar 2,859 dapat diartikan bahwa rata-rata kontribusi variabel lain diluar model memberikan dampak positif terhadap tingkat kepuasan wisatawan.

3. Berdasarkan persamaan diatas, menunjukan jika $\mathrm{X}_{1}, \mathrm{X}_{2}, \mathrm{X}_{3}, \mathrm{X}_{4}, \mathrm{X}_{5}$ ditambah sebesar satu satuan maka tingkat kepuasan pelanggan akan meningkat sebesar $0,007 \mathrm{X}_{1} ; 0,406 \mathrm{X}_{2} ; 0,023 \mathrm{X}_{3} ; 0,285 \mathrm{X}_{4} ; 0,417 \mathrm{X}_{5}$ satuan.

Berdasarkan Tabel 13. juga menunjukkan nilai thitung dari setiap variabel independent dalam penelitian ini, yang akan dibandingkan dengan nilai ttabel dengan menggunakan tingkat kepercayaan (confidence interval) 95 persen atau $\alpha$ $=0,05 \mathrm{dan} \mathrm{df}=115$ maka diperoleh nilai ttabel sebesar 1,658.

Hasil pengujian hipotesis secara parsial menunjukkan bahwa variabel sense $\left(\mathrm{X}_{1}\right)$ memiliki nilai thitung sebesar 0.054 lebih kecil dari nilai tabel yang berarti variabel komitmen tidak berpengaruh terhadap tingkat kepuasan pelanggan serta nilai signifikansi sebesar 0,957 lebih besar dari nilai $\alpha$ yang berarti variabel sense tidak siginifikan terhadap tingkat kepuasan wisatawan, dimana jika variabel sense ditingkatkan sebesar satu satuan maka tingkat kepuasan wisatawan akan bertambah sebesar 0,007 satuan. Hal ini berarti keputusannya adalah Ho1 diterima dan $\mathrm{Ha}_{1}$ ditolak, artinya secara parsial variabel sense tidak berpengaruh signifikan terhadap tingkat kepuasan wisatawan di Kabupaten Belitung.

Hasil pengujian hipotesis secara parsial menunjukkan bahwa variabel feel $\left(\mathrm{X}_{2}\right)$ memiliki nilai thitung sebesar 4,974 lebih besar dari nilai tabel yang berarti variabel feel berpengaruh secara positif terhadap tingkat kepuasan wisatawan serta nilai signifikansi sebesar 0,000 lebih kecil dari nilai $\alpha$ yang berarti variabel feel 
berpengaruh signifikan terhadap tingkat kepuasan wistawan, dimana jika variabel feel ditingkatkan sebesar satu satuan maka tingkat kepuasan wisatawan akan bertambah sebesar 0,406 satuan. Hal ini berarti keputusannya adalah $\mathrm{Ho}_{2}$ ditolak dan $\mathrm{Ha}_{2}$ diterima, artinya secara parsial variabel feel berpengaruh signifikan terhadap tingkat kepuasan wisatawan di Kabupaten Belitung.

Hasil pengujian hipotesis secara parsial menunjukkan bahwa variabel think $\left(\mathrm{X}_{3}\right)$ memiliki nilai thitung sebesar 0.162 lebih kecil dari nilai tabel yang berarti variabel think tidak berpengaruh terhadap tingkat kepuasan wisatawan dengan nilai signifikansi sebesar 0,872 lebih besar dari nilai $\alpha$ yang berarti variabel think tidak siginifikan terhadap tingkat kepuasan pelanggan, dimana jika variabel think ditingkatkan sebesar satu satuan maka tingkat kepuasan wisatawan akan bertambah sebesar 0,023 satuan. Hal ini berarti keputusannya adalah Ho3 ditolak dan Haz diterima, artinya secara parsial variabel think tidak berpengaruh signifikan terhadap tingkat kepuasan wisatawan di Kabupaten Belitung.

Hasil pengujian hipotesis secara parsial menunjukkan bahwa variabel act $\left(\mathrm{X}_{4}\right)$ memiliki nilai thitung sebesar 3.834 lebih besar dari nilai tabel yang berarti variabel act berpengaruh positif terhadap tingkat kepuasan wisatawan dengan nilai signifikansi sebesar 0,000 lebih kecil dari nilai $\alpha$ yang berarti variabel act berpengaruh signifikan terhadap tingkat kepuasan wisatawan, dimana jika variabel act ditingkatkan sebesar satu satuan maka tingkat kepuasan wisatawan akan bertambah sebesar 0,285 satuan. Hal ini berarti keputusannya adalah $\mathrm{Ha}_{4}$ diterima dan $\mathrm{Ho}_{4}$ ditolak, artinya secara parsial variabel act berpengaruh signifikan terhadap tingkat kepuasan wisatawan di Kabupaten Belitung.

Hasil pengujian hipotesis secara parsial menunjukkan bahwa variabel relate (X5) memiliki nilai thitung sebesar 4.284 lebih besar dari nilai tabel yang berarti variabel relate berpengaruh positif terhadap tingkat kepuasan wisatawan dengan nilai signifikansi sebesar 0,000 lebih kecil dari nilai $\alpha$ yang berarti variabel relate berpengaruh signifikan terhadap tingkat kepuasan pelanggan, dimana jika variabel relate ditingkatkan sebesar satu satuan maka tingkat kepuasan pelanggan akan bertambah sebesar 0,285 satuan. Hal ini berarti keputusannya adalah Ha5 diterima dan $\mathrm{Ho}_{5}$ ditolak, artinya secara parsial variabel relate berpengaruh signifikan terhadap tingkat kepuasan wisatawan di Kabupaten Belitung.

Berdasarkan hasil pengujian hipotesis secara parsial dari kelima variabel independent yang meliputi sense, feel, act, think dan relate diketahui bahwa variabel sense dan variabel think tidak memiliki pengaruh yang signifikan erhadap tingkat kepuasan pelanggan yaitu para wisatawan di Kabupaten Belitung, sedangkan tiga variabel lainnya yaitu feel, act dan relate memiliki pengaruh yang signifikan terhadap tingkat kepuasan wisatawan di Kabupaten Belitung. Dari ketiga variabel tersebut, variabel feel memiliki tingkat pengaruh signifikan yang paling besar terhadap tingkat kepuasan wisatawan, yang juga didukung dengan 77,39 persen tanggapan positif responden. Kemudian variabel relate merupakan variabel yang juga memiliki tingkat pengaruh signifikan terbesar kedua terhadap tingkat kepuasan wisatawan, didukung dengan 84,93 persen tanggapan positif. Variabel act merupakan variabel berikutnya yang memiliki pengaruh signifikan terhadapat tingkat kepuasan wisatawan, didukung 85,80 persen tanggapan positif. 
Analisis dari hasil penelitian menunjukkan bahwa tiga variabel dalam penelitian ini, yaitu variabel feel, relate dan act berpengaruh signifikan dan berbanding lurus positif terhadap tingkat kepuasan wisatawan.

\section{Koefisien Determinasi}

Berdasarkan Tabel 14. berikut menunjukkan bahwa nilai $\mathrm{R}$ sebesar 0,908 yang berarti pengaruh kelima variabel independent yaitu sense, feel, think, act dan relate secara bersama-sama terhadap tingkat kepuasan wisatawan adalah sangat kuat. Sedangkan nilai R Square sebesar 0,825 berarti kelima variabel independent tersebut berpengaruh sebesar 82,5 persen dan sisanya 17,5 persen dipengaruhi oleh faktor lain diluar objek penelitian.

Tabel 14. Uji Koefisien Determinasi

Model Summary

\begin{tabular}{|l|l|r|r|r|}
\hline Model & $\mathrm{R}$ & R Square & \multicolumn{1}{|c|}{$\begin{array}{c}\text { Adjusted R } \\
\text { Square }\end{array}$} & $\begin{array}{c}\text { Std. Error of } \\
\text { the Estimate }\end{array}$ \\
\hline 1 & $.908^{\mathrm{a}}$ & .825 & .817 & .836 \\
\hline
\end{tabular}

a. Predictors: (Constant), Relate, Sense, Think, Act, Feel

Sumber: Hasil Penelitian, 2019 (IBM SPSS Statistics 22, diolah)

Hasil penelitian ini sejalan dengan beberapa penelitian terkait experiential marketing, seperti pada penelitian Barimbing (2015) pada studi kasus Mujigae Resto Ciwalk Bandung diperoleh hasil bahwa 88,4 persen pengaruh terhadap kepuasan pengunjung. Gresivonda (2014) dalam penelitiannya pada rumah makan Joyo Taman Pinang, Sidoarjo menunjukkan pengaruh seluruh variabel sebesar 51,2 persen secara simultan terhadap kepuasan pelanggan. Dapat disimpulkan sementara bahwa kepuasan konsumen pada rumah makan dipengaruhi oleh salah satunya melalui penerapan dan pengembangan experiential marketing.

\section{SIMPULAN}

Berdasarkan hasil penelitian dan pembahasan, maka ditarik simpulan sebagai berikut:

1. Dari empat variabel independent penelitian, terdapat tiga dimensi yaitu feel, act dan relate berpengaruh signifikan terhadap tingkat kepuasan wisatawan pada rumah makan wisata di Kabupaten Belitung. Hal ini telah dibuktikan melalui uji signifikansi parameter individual dan dikuatkan dengan hasil analisis deskripsi variabel.

2. Secara berurutan menyesuaikan tingka pengaruhnya, dimensi feel, relate dan act dapat menjadi pedoman awal untuk meningkatkan nilai tingkat kepuasan wisatawan dan bermuara pada peningkatan jumlah wisatawan di Kabupaten Belitung.

Variabel feel yang menjadi fokus wisatawan didasarkan pada tiga indikator yaitu:

a. Keramahtamahan karyawan rumah makan wisata dalam memberikan pelayanan kepada wisatawan.

b. Kecepatan dalam memberikan pelayanan kepada wisatawan mulai sejak wisatawan datang hingga menyelesaikan kunjungannya. 
c. Suasana santai yang dihadirkan oleh rumah makan wisata, dikarenakan wisatawan datang untuk menghabiskan waktunya tanpa ada batasan waktu.

Pengalaman wisatawan pada variabel relate dapat difokuskan pada tiga indikator berikut:

a. Hubungan oleh rumah makan wisata kepada wisatawan dilakukan dengan komunikasi dua arah

b. Kunjungan wisatawan pada rumah makan wisata didominasi berdasarkan feedback pengalaman wisatawan lain

c. Penyajian menu yang disesuaikan dengan kebutuhan dan selera wisatawan

Berkaitan dengan variabel act, fokus utama berada pada indikator:

a. Wisatawan membutuhkan interaksi yang komunikatif dengan para pelayan rumah makan wisata

b. Penyesuaian pelayanan sebaiknya dilakukan bagi para wisatawan, dikarenakan memiliki kebutuhan berbeda

c. Penciri rumah makan wisata dengan karakter sebagai tempat yang cocok untuk berkumpul bersama keluarga atau kerabat

Terdapat beberapa kebijakan ataupun pendekatan yang bisa dijalankan dalam mempertahankan maupun meningkatkan nilai kepuasan pelanggan, antara lain:

1. Melakukan pendekatan kognitif kepada para wisatawan dalam memahami kebutuhan dan keinginannya dalam berwisata.

2. Memperbaiki interaksi dan intensitas hubungan antara Kabupaten Belitung dengan industri rumah makan wisata melalui peningkatan kuantitas dan kualitas media komunikasi seperti jejaring sosial online khususnya.

3. Pelayanan ketika melaksanakan kegiatan wisata selama di Kabupaten Belitung menjadi tolok ukur utama dalam melakukan penilaian. Menghadirkan pelayanan dengan menggabungkan interaksi aktif dan komunikasi dua arah, menjadi hal utama bagi wisatawan.

\section{DAFTAR PUSTAKA}

Badan Pusat Statistik Kabupaten Belitung. (2019). Kabupaten Belitung Dalam Angka 2019. Kabupaten Belitung: Badan Pusat Statistik

Badan Pusat Statistik Kabupaten Belitung. (2018). Kecamatan Sijuk Dalam Angka 2018. Kabupaten Belitung: Badan Pusat Statistik

Barimbing, Citra Aptri Adolia dan Devilia Sari. (2015). Pengaruh Experiental Marketing Terhadap Kepuasan Pelanggan - Studi pada Pelanggan Mujigae Resto Ciwalk Bandung. eProceedings of Management Telkom University: Vol. 2 No.1 Edisi April 2015:770-777.

Ghozali, I. (2011). Aplikasi Analisis Multivariate Dengan Program IBM SPSS 19, Edisi Kelima, Badan Penerbit Universitas Diponegoro, Semarang. 
Gresivonda, \& Mudji Astuti, The Effect of Experiential Marketing Implementation Toward Customer Satisfaction at Joyo Restaurant Taman Pinang Sidoarjo. Jurnal Bisnis, Manajemen dan Perbankan, Vol. 1 No. 1 Edisi Maret 2015:1-22

Karo, P. K. (2020). Analisis Pengaruh Experiential Marketing Terhadap Tingkat Kepuasan Peserta Sports Event Jakabaring Wonderful Run Palembang. Pusaka: Journal of Tourism, Hospitality, Travel and Business Event, 2(2), 127-135. https://doi.org/10.33649/pusaka.v2i2.32

Karo, P. K., Harahap, Z., \& Hamonangan, S. (2020). Persepsi dan Ekspektasi Wisatawan Terhadap Kualitas Pelayanan Rumah Makan Wisata di Desa Terong, Kabupaten Belitung. Jurnal Akademi Pariwisata Medan, 1(2), 74-90.

Murti, B. (2013). Desain dan ukuran sample untuk penelitian kuantitatif dan kualitatif di bidang kesehatan. Yogyakarta: Gadjah Mada University Press

Nugroho, B. A. (2005). Strategi Jitu Memilih Metode Statistik Penelitian dengan SPSS. Yogyakarta: Andi

Schmitt, B. H. (2011). Experiential Marketing How to Get Customer Sense, Feel, Think, Act, and Relate to Your Company and Brand. New York: The Free Press.

Schmitt, B. H. (2014). The Current State and Future of Brand Experience. Journal of Brand Management. Volume. 21 NO. 16, pp. 727-733.

Sugiyono. (2017). Metode Penelitian Kualitatif: Untuk penelitian yang bersifat: eksploratif, enterpretif, interaktif dan konstruktif. Bandung: Alfabeta

Tjiptono, F. 2014. Pemasaran Jasa - Prinsip, Penerapan, dan Penelitian. Yogyakarta: Penerbit. Andy.

Yeh, Tsu-Ming, Shun-Hsing Chen dan Tsen-Fei Chen. (2019). The Relationships among Experiential Marketing, Service Innovation, and Customer Satisfaction - A Case Study of Tourism Factories in Taiwan. Sustainability Journal, Sustainability 2019, 11, 1041; doi:10.3390/su11041041

Zulganef. (2006). Pemodelan Persamaan Struktur dan Aplikasinya menggunakan AMOS 5. Bandung: Pustaka 